\title{
A Comparitive Study of Magical Realism in One Hundred Years of Solitude and the Legends of Khasak
}

\author{
Narghese Hussair \\ M.A. Comparative Literature \\ University of Hyderabad \\ Thrissur, Kerala, India \\ narghesubaida@gmail.com
}

\begin{abstract}
Macondo like Malgudi, a fictional town created by the Latin American novelist Gabriel Garcia Marquez in his magnum opus One Hundred Years of Solitude with its cosmic spirituality and surreal characters lies deep-hearted in the minds of literary lovers all over the world. But far away from Colombian hills and miles apart from its vast seas lies Vijayan's Khasak. A fine work of magical realism which changed the trajectory of Malayalam novel that got lost in translation like many other great works of Malayalam literature. This paper attempts to critically analyze both these novels in their socio-cultural and post-colonial perspectives and how they contribute to the genre of magical realism.
\end{abstract}

Keywords: Realism, Magical Realism, Latin America, Khasak, Macondo Just as realism was a response to the romantic age, magical realism emerged as a reaction to realism. It was first introduced by Franz Roh, a German critic in 1925, later popularized by the Latin American culture and in India vividly by the works of Salman Rushdie and in Japan by the author Haruki Murakami. Magical realism is often confused with 
fantasy. Magical realism exists as a fine amalgamation between rationale and fantasy. The story is set in a realistic environment with a tint of magical elements to it. Harry Potter is often regarded as a fantasy novel because the setting is completely supernatural and unreal whereas in magical realism there are only certain instances of magic or fantasy intermixed in the everyday life of the characters.

World cinema has also experimented with a bit of magical realism. It was Lijo Jose Palissery in his 2012 Malayalam movie "Amen "first experimented with this genre in Malayalam. The Jean Pierre Jeunet directed French classic movie "Amelie" is also a fine example of magical realism in cinema. Another popular example is the Woody Allen directed movie "midnight in Paris", set in a surreal scene where all the great artists of the lost generation gather alive to solve the existential crisis of a young American stuck in the beauty of ethereal Paris. The Netflix original "Narcos", an account of the life of the drug lord Pablo Escobar set against the backdrop of violent Colombia begins by the lines "there is a reason that magical realism was born in Colombia". Magical realism is the paradoxical coexistence of rationality and supernatural making literature a little bit more fantastic and surreal.

O.V Vijayan, a phenomenal Malayalam writer famous for his spiritual ideologies and intellectual psyche was a political commentator, cartoonist, a columnist, and a Sahitya Akademi winning novelist. It took 12 years for him to finish writing "Khasakhinte Ithihaasam" [ legends of khaskh ] in 1969. The story is set in a half-real town of khasak , in real " Thasarack " is a small hamlet in the picturesque countryside of Palakkad where Vijayan once spent quality time living when his sister taught in a school. Like Macondo, Khasak is a village that is stuck in time with little connection to the outside world. Marquez took a span of five years to finish the novel and Macondo is the microcosm of his native Aracata in Columbia and the writer said that he wrote the novel inspired by the tales that his 
grandmother once narrated to him. Khasakinte Ithihasam is Latin American in aesthetics and Arabian in narration. Both these novels are multi-faceted and absurd

One Hundred Years of Solitude is a novel about the revolutionary journey of seven generations of the Buendia family that witness massacres, calamities, revelations, and tragedies. The legends of Khasak is the spiritual journey of an undergraduate drop out Ravi who ended up as a school teacher in a village where myths, superstitions, and caste are an integral part of people's lives. Ravi's redemptive journey after his incestual affair with his stepmom which drove him to great guilt is one that is very prominent in the magical characters of Marquez's works. In the legends of Khasak, it was the existential crisis of Ravi that is reverberated throughout the novel whereas in one hundred years of solitude it is the crisis of Macondo itself and the solitude experienced by Ursula who sees the seven generations of her family growing and decaying away. Both novels have striking similarities even though the cultural background of these two differs extensively. In one hundred years of solitude, it is hard to keep a track of characters because of the density in which Marquez has written them, they are all layered and dimensional filled with rich imagery and a nonlinear narrative. In legends of Khasak when the story unravels, it travels through a plethora of powerful and memorable characters through Ravi's spiritual journey whether it's the village beauty Maimuna from Khasak or Remedios the beauty from Macondo or Appukili or memo, or Madhavan Nair.

Both novels also deal with an interplay of a divine relation between physics and cosmic. Ravi was a genius and was offered a scholarship at Princeton to study astrophysics. When closely analyzing Ravi's character we find similarities that of Melquiades, the gypsy who brought the technological marvels to Macondo. Melquiades becomes Marquez's prototype of magical realism. He comes back from death through a mystic rebirth. His quest for knowledge even after he is dead can be paralleled with Ravi's journey. Unknowingly both 
novels deal with the idea of purpose. Marquez and Vijayan are successful in evoking this feeling in the readers with the fantastic cosmic realm that both novels create. As Vijayan said in his novel," it moves along, if you will, in a deeply emotional mode in a constant search for cosmic mystery".

The inhabitants of both the lands despise modernization and education as they thought that it would hamper their tradition and custom with the scientific intervention of technology. Their illiteracy was a barrier to their outside world, hence both the worlds were stuck in a time loop. As Ravi first teaches in the school, he is seen as a threat to the entire system and village. The Mollakka thought Ravi's educational policies would disrupt the Madrassa studies. People of khasak believed that diseases were caused when gods were angry like smallpox was believed to be caused by Pothi [ bagavati]. In Macondo, the members of the Buendia family go on exploring every possible marvel on earth but education is not trusted . Tradition is the patriarch that runs the family. As a result in both novels, superstitions and taboos are complex and volatile. Alla Pitcha, the Moulavi of Khazak, considers Ravi as a natural foe as he considers modern education as devil sciences and Anglican.

The socio-historical background of the novel is also intertwined with violence, revolutions, and invasions. Vijayan had a deep romance with communism until he was disheartened by the killing of Hungarian communist politician Imre Nagy by the soviet government which shattered the mind of the young writer and he dropped his ideologies about communism and Vijayan portrayed his protagonist as a spiritual Indian mystic and not a revolutionary

Ravi was very passive in his outlook towards life. Just like Remedios the beauty whom one day evaporated straight into heaven breaking the hearts of all her lovers, Ravi also enjoys the biting of a poisonous snake. He does it just like Porphyria or Ophelia. He takes a sadistic pleasure in ending his life when Vijayan doesn't mention if the snake bite was 
accidental or suicidal. Ultimately Ravi's truth was found through death. Lust and sexuality are viewed in both novels as something guilty and at the same time incurable. Ravi's affair with his stepmom and his betrayal for his lost love Padma all contributes to his sinful mind. Pedophilia is not seen as an abnormal thing in the majority of Marquez's writings. Critics often label Florentino Ariza the main protagonist of the novel "love at the time of cholera" as a child molester. In one hundred years of solitude Colonel Aureliano Buendia falls in love with the seven-year-old pre-pubescent Remedios Mascot, and the entire novel is filled with adultery and sinful lust.

In both novels, the writers have used strong imagery. The image of water and image of time is predominated. Ravi spends a lot of time in water imagining that he can go back to his mother's womb again just to sleep in peace. In Macondo one day the rain begins on the night of the Banana Massacre and does not stop for almost five years. Rain symbolizes both destruction and warmth here. Marquez does a commendable job in portraying the female characters of the novel but Vijayan fails in this case. He failed to add more memorable women characters to his magnum opus. In both, the women of the novel are deeply sexualized and always exist according to the whims and fancies of the men they are related to. Ursula, the powerful matriarch of the Buendia family whom I regard as the main protagonist of Marquez's novel witnesses generations thriving as the time went by. She remained as the unbreakable backbone of the family. In Vijayan's novel, unfortunately, women are all forgotten lovers, prostitutes and mothers

It was O.V Vijayan itself who translated his novel into English nearly three decades after its publication in 1994. That is the sole reason why Khasak was unknown to the literary world for such a long time because of this untimely translation. Greggory Rabass translated one hundred years of solitude in 1982 after three years of its publication. It became an instant bestseller and swept off the literary world with the genius of magical realism. 
These novels emerged from the so-called third world countries which have seen the grotesque effects of years of colonialism and imperialism and hence are a fine example of post-colonial literature. In the post-colonial India, with its Gandhian values and Nehru's vision of modern India, prominent Malayalam writers like M.T Vasudevan Nair, T. Padmanabhan, N. P Muhammed, Madhavi Kutty created a breakthrough in Malayalam literature from the romantic genre with a new tradition portraying alienation, crisis, and trauma of young India. It was a psychological reaction to social and political transformation. The literature that was produced in this period was mostly existential like Vaikom Muhammed Basheer's stories about prison and freedom struggle. Authors like Punnathil Kunjabdulllah, M. Mukundan wrote about a spiritual journey in the wake of post-colonial India, free from sentimentality and pretentious verbalism as that of the Victorian novels. In one hundred years of solitude just like Achebe's Things Fall Apart, the Buendia family built up a whole town and tribe. But the advent of Melquiades and Don Apolinar Macote brings catastrophe to Macondo, in the same way, the arrival of Spaniards disturbs the peaceful life of Colombia. After independence in Colombia, a series of political conflicts between the liberals and conservatives break out and this results in a war of thousand days. In the novel, this war became significant in the backdrop of the Buendia family.

The process of colonization affected the national identity of people. These writers aim was to bring back this lost identity. The purpose of all post-colonial novels is to create awareness in the colonized minds to bring back the real freedom that was ones lost. The one admirable quality of magical realism is its timelessness which is significantly evident in both the novels. Khasak was Vijayan's Macondo and both these novels portray the complexities of the human mind. Indeed certain things in life can be purely determined as illogical in terms of 
the state of being and expression. It is these illogical realities of life resonating with the cosmic magic of every day that remains as the ultimate crux of both these novels. 


\section{Works Cited}

Bell-Villada, Gabriel Garcia Marquez's One Hundred Years of Solitude: A Casebook Oxford: Oxford University, 2002.

Marquez, Gabrial Garcia. One Hundred Years of Solitude: Harper and Row Press, Colombia.1967

Roh, Franz, and Irene Guenther. Magical realism: Theory, history, community. Duke University Press, 1995. 